TRIDARMA: Pengabdian Kepada Masyarakat (PkM), 5 (1) (2022) 32-38

Published by: Institute of Computer Science (IOCS)

TRIDARMA: Pengabdian Kepada Masyarakat (PkM)

Journal homepage: www.iocscience.org/ejournal/index.php/abdimas

\title{
Pelatihan Penggunaan Aplikasi E-RT Berbasis Web Pada Rukun Tetangga 004 Utan Kayu Selatan Jakarta Timur
}

\author{
Kevin Dibert ${ }^{1}$, Indah Fajarwati ${ }^{2}$, Triningtias Silalahi ${ }^{3}$, Ahmad Fauzi ${ }^{4}$ \\ Program Studi Sistem Informasi
}

Fakultas Teknologi Informasi, Universitas Nusa Mandiri, Jl. Raya Jatiwaringin No 2 Jakarta Timur, Indonesia

Email: 1dibert.kevin@gmail.com 2. fajarwatii513@gmail.com³.

triningtiassilalahi@gmail.com4.ahmad.azy@nusamandiri.ac.id

Abstrak

\begin{abstract}
Saat ini dalam pengurusan surat pengantar membutuhkan waktu lebih lama dikarenakan kesibukan dari pengurus Rukun Tetangga diperparah dengan adanya pandemi yang membuat pengurusan menjadi lebih lama karena tidak bolehnya atau dikurangi pertemuan dan aturan menjaga jarak. Tujuan pengabdian masyarakat yang kami lakukan adalah mempermudah aktivitas pembuatan surat dengan melatih pengurus Rukun Tetangga memanfaatkan aplikasi pelayanan publik. Dengan adanya aplikasi pelayanan tersebut diharapkan dapat mengatasi waktu proses pembuatan surat pengantar dan menghindari penyebaran virus selama pandemi. Program E-RT diharapkan mendapat perhatian penuh dari pemerintah dan pihak terkait, adanya standar pelayanan baku dan infrastruktur yang memenuhi, faktor penghambatnya yaitu animo masyarakat, kurangnya dukungan pihak internal, dan kurangnya maintenance sarana prasarana, harus ada untuk diperlukan informasi lebih giat, namun tidak sekedar sosialisasi, dan pelatihan kepada masyarakat untuk mengoperasikan secara online serta diadakan akuntabilitas pendanaan yang transparan. Sistem komputerisasi sangat dibutuhkan untuk mempermudah sebuah pelayanan dan pemberian informasi didalam melakukan suatu proses pelayanan masyarakat. Salah satu kegiatan pelayanan yang selalu dilakukan setiap harinya adalah pelayanan pembuatan segala bentuk Surat Keterangan, Surat Pemberitahuan yang diperuntukkan untuk warga yang berisikan Himbauan/informasi, pendataan penduduk yang kurang mampu di wilayah Rukun Tetangga untuk kondisi saat ini masih dilakukan secara manual. Pengolahan data secara manual bukanlah suatu hal yang salah, namun cara tersebut kurang efektif untuk melakukan pengolahan dan perhitungan data yang besar, dan hal ini dapat mengakibatkan terjadinya kehilangan data. Kesalahan-kesalahan yang tidak diinginkan itu akan sangat merugikan untuk perkembangan pedataan warga.
\end{abstract}

Kata Kunci: Sistem, Aplikasi, Pelayanan Publik, Surat, E-RT dan Masyarakat.

\section{Pendahuluan}

Saat ini dalam pengurusan surat pengantar membutuhkan waktu lebih lama dikarenakan kesibukan dari pengurus Rukun Tetangga diperparah dengan adanya pandemi yang membuat pengurusan menjadi lebih lama karena tidak bolehnya atau dikurangi pertemuan dan aturan menjaga jarak. Tujuan pengabdian masyarakat yang kami lakukan adalah mempermudah aktivitas pembuatan surat dengan melatih pengurus Rukun Tetangga memanfaatkan aplikasi pelayanan publik. Dengan adanya aplikasi pelayanan tersebut diharapkan dapat mengatasi waktu proses 
pembuatan surat pengantar dan menghindari penyebaran virus selama pandemi. Perlu dipahami aplikasi pelayanan tersebut juga memiliki dampak buruk karena berkurangnya sosialisasi dan perkenalan antar warga(Hersya Pratama et al., 2128). Dalam hal teknologi informasi dapat digunakan untuk melakukan otomatisasi semua proses kerja atau pelayanan yang baik untuk kebutuhan eksternal maupun internal. Sistem komputerisasi sangat dibutuhkan untuk mempermudah sebuah pelayanan dan pemberian informasi didalam melakukan suatu proses pelayanan masyarakat. Salah satu kegiatan pelayanan yang selalu dilakukan setiap harinya adalah pelayanan pembuatan segala bentuk Surat Keterangan, Surat Pemberitahuan yang diperuntukkan untuk warga yang berisikan Himbauan/informasi, pendataan penduduk yang kurang mampu di wilayah Rukun Tetangga untuk kondisi saat ini masih dilakukan secara manual (Susano \& Alva Mustika, 2017)

Setiap masyarakat dilingkungan Rukun Tetangga 004 Rukun Warga 002 kelurahan Utan Kayu Selatan kecamatan Matraman memiliki kepentingan yang berbeda-beda jadi tidak selalu ketua Rukun Tetangga berada dirumahnya untuk membantu masyarakat membuatkan surat pengantar seperti surat kematian, surat domisili, surat pembuatan Kartu Tanda Penduduk (KTP) dan lain-lain dari ketua Rukun Tetangga. Dan juga masyarakat memiliki pekerjaan dengan waktu yang berbedabeda, ketua Rukun Tetangga 004 Rukun Warga 002 juga bekerja sehingga tidak selalu ada dirumah. Selama ini masih menggunakan kertas sebagai pembuatan surat keterangan, buku pencatatan surat keluar masuk di Rukun Tetangga cepat rusak. Susah untuk mencari data-data yang lama, memerlukan waktu yang cukup lama dan tidak efisien (Wahyudin, Fredy Rizqi Maulana, Mohammad Faisol, Yolanda, 2021)

Dalam pelaksanaan tugas dan fungsinya, tidak jarang ditemukan berbagai permasalahan di tingkat RT, baik yang muncul dari internal pengurus RT sendiri maupun dari eksternal pengurus RT. Pelayanan yang masih manual dan membutuhkan tenaga serta waktu yang lama, kurang tersosialisasinya program Pemerintah Daerah maupun program RT setempat, serta kurangnya fasilitas pendukung kinerja, merupakan contoh dari berbagai permasalahan yang kerap terjadi. Untuk itu, dalam kegiatan Pengabdian kepada Masyarakat (PKM) Universitas Multimedia Nusantara (UMN) diajukan solusi untuk mengatasi berbagai permasalahan dalam proses pelayanan RT tersebut, yakni berupa aplikasi e-RT(Seng Hansun, Muh. Salehuddin, 2021)

Pendataan warga pada RT 04 Kalisuren adalah untuk menghasilkan data warga yang tepat dan akurat, agar dapat disampaikan dengan baik kepada yang membutuhkan. Sistem pendataan warga pada RT 04 Kalisuren masih dilakukan secara manual seperti pembuatan laporan dan pencatatan. Pengolahan data secara manual bukanlah suatu hal yang salah, namun cara tersebut kurang efektif untuk melakukan pengolahan dan perhitungan data yang besar, dan hal ini dapat mengakibatkan terjadinya kehilangan data. Kesalahan-kesalahan yang tidak diinginkan itu akan sangat merugikan untuk perkembangan pedataan warga. (Pauziah et al., 2020)

\subsection{Tujuan Kegiatan}

Tujuan kegiatan ini adalah untuk Karena sistem ini bisa mengatasi beberapa permasalahan kesulitan warga dalam memperoleh layanan administrasi surat pengantar Rukun Tetangga yang cepat dan tanpa batas dari dimensi ruang dan waktu. Warga menyambut baik keberadaan sistem aplikasi Surat Pengantar Rukun Tetangga berbasis website ini, warga sangat antusias dan akan menggunakan system ini pada saat mengurus Surat Pengantar Rukun Tetangga.

\subsection{Manfaat kegiatan}

Warga yang telah mengisi formulir pendaftaran secara lengkap, maka pada saat akan membutuhkan Surat Pengantar Rukun Tetangga cukup memasukkan data sesuai Kartu Tanda Penduduk atau Kartu Keluarga, sehingga pada saat proses penginputan data menjadi sangat cepat. Kepada ketua Rukun Tetangga selaku petugas Validator untuk dapat melakukan update data secara berkelanjutan. Kepada ketua Rukun Tetangga dan juga pengurus Rukun Tetangga setempat, agar secara rutin setiap hari melakukan pengecekan pada menu permintaan Surat Pengantar sehingga proses dalam pembuatan Surat Pengantar dapat berjalan cepat dan tepat. 


\subsection{Luaran Pengabdian Kepada Masyarakat}

Menjadikan aplikasi pelayanan publik mempermudah dan solusi warga dalam pembuatan surat pengantar yang dahulu harus datang mengunjungi rumah perangkat Rukun Tangga namun sekarang dapat dilakukan secara cepat. Mendukung program pemerintah dalam rangka pembatasan sosial untuk memberantas pandemi virus covid-19 sehingga warga Rukun Tangga 04 Kelurahan Utan Kayu Selatan terhindar dari penyebaran virus. Dari pelatihan yang kami lakukan dapat meningkatkan pengetahuan dan keterampilan perangkat Rukun Tangga serta warga dalam menggunakan teknologi internet secara positif. Mempermudah warga untuk dilayani oleh perangkat Rukun Tangga untuk pengurusan surat ijin dan pengantar ke kelurahan.

\section{Realisasi Kegiatan}

\subsection{Bentuk Kegiatan \& Jadwal, Serta Tempat Kegiatan}

\section{a. Metode Pelaksanaan Kegiatan}

Pengabdian masyarakat yang dilakukan dengan cara memberikan pelatihan penggunaan aplikasi E-RT kepada warga Rukun Tangga 004 Kelurahan Utan Kayu Selatan dan juga kepada pengurus. Metode pemahaman tentang aplikasi dilaksanakan selama 1 hari dengan memberikan pemahaman dan arahan bagaimana mengakses website untuk dapat menggunakan aplikasi. Metode pendampingan dilakukan selama 2 hari untuk memberikan pengertian dan pelatihan tambahan terhadap warga dan pengurus yang belum begitu paham.

\section{b. Waktu Efektif Pelaksanaan Kegiatan}

Kegiatan Pelaksanaan Pengabdian Kepada Masyarakat ini akan dilaksanakan pada Tanggal 2 September 2021 sampai dengan 31 November 2021 dengan rincian sebagai berikut:

Tabel 1. Jadwal Pelaksanaan

\begin{tabular}{|c|c|c|c|c|c|c|c|c|c|c|c|c|c|}
\hline \multirow[b]{3}{*}{ No } & \multirow[b]{3}{*}{ Kegiatan } & \multicolumn{12}{|c|}{ Jadwal Pelaksanaan } \\
\hline & & \multicolumn{4}{|c|}{ September } & \multicolumn{4}{|c|}{ October } & \multicolumn{4}{|c|}{ November } \\
\hline & & 1 & 2 & 3 & 4 & 1 & 2 & 3 & 4 & 1 & 2 & 3 & 4 \\
\hline 1 & Pengamatan Wilayah & & & & & & & & & & & & \\
\hline 2 & Pemetaan Masalah & & & & & & & & & & & & \\
\hline 3 & Pembuatan Aplikasi & & & & & & & & & & & & \\
\hline 4 & Sosialisasi Aplikasi & & & & & & & & & & & & \\
\hline
\end{tabular}

Pelaksanaan Pengabdian Masyarakat dimulai pada minggu ke 2 selama 3 minggu pada bulan November bersamaa dengan kegiatan rutin arisan pada lingkungan Rukun Tangga 004 Kelurahan Utan Kayu Selatan.

\section{c. Tempat Kegiatan}

RT 04 Kelurahan Utan Kayu Selatan mempunyai total 150 kepala keluarga dengan kurang lebih 65 rumah. Sebelah utara berbatasan dengan JI Nanas III, timur berbatasasan dengan Gang Melati VI, Sebelah barat berbatasan langsung dengan JI. Nanas serta Selatan berbatasan dengan JI Melati VI. Jika dilihat menggunakan layanan Peta Google terletak antara koordinat $6^{\circ} 11^{\prime} 59.8^{\prime \prime S} 106^{\circ} 52^{\prime} 11.2^{\prime \prime E}$ dan 6²'01.6"S 106²'11.3"E

\subsection{Materi}

Pelaksanaan kegiatan sosialisasi aplikasi E-RT terdiri dari:

a. Menginformasikan website yang dapat diakses melalui telepon selular ataupun laptop yang terhubung ke internet dengan mengakses http://e-rtutankayu004-002.online

b. Pengenalan aplikasi E-RT menggunakan laptop kepada warga dan pengurus RT dengan memperlihatkan menu menu yang akan digunakan oleh warga dan pengurus.

c. Pendampingan kepada warga dan pengurus Rukun Tangga saat mencoba langsung mengakses aplikasi. 


\subsection{Masyarakat Sasaran}

Wilayan Rukun Tangga 004 Kelurahan Utan Kayu Selatan dapat dikategorikan menjadi dua tipe warga, yaitu penduduk asli dan warga pendatang yang hanya mengkontrak di wilayah tersebut. Kegiatan Sosialisasi Aplikasi E-RT ini dimaksudkan untuk menyasar seluruh tipe warga tersebut agar pendataan warga menjadi lebih cepat dan efisien dari segi waktu serta tenaga karena sudah dimudahkan menggunakan kemajuan teknologi berbasis WEB.

\section{Tinjauan Hasil Yang Di Capai}

a. Pelayanan publik pengurusan surat pengantar Rukun Tangga dapat dilakukan dengan cepat dan tepat.

b. Ketua Rukun Tangga dan perangkat lainnya juga dapat melayani warga dengan baik tanpa batasan ruang dan waktu serta tatap muka sehingga mengganggu aktivitas masing masing.

c. Pelayanan public E-RT berbasis website dengan memanfaatkan teknologi informasi dapat menjadi solusi untuk mempermudah masyarakat dalam pembuatan surat pengantar Rukun Tangga.

d. Pelayanan public E-RT dapat menjadi contoh baik bagi Rukun Tangga lainnya untuk pelayanan yang modern.

e. Mengangkat citra Universitas Nusa Mandiri sebagai perguruan tinggi yang telah memeiliki branding sebagai perguruan tinggi yang unggul di bidang system informasi untuk resource sharing bagi pengembangan wilayan sekitar Rukun Tangga 004 Kelurahan Utan Kayu Selatan. Jika aplikasi ini berhasil maka diprediksi dapat digunakan dan diimplementasikan bagi pelayanan pengurusan surat pengantar Rukun Tangga bagi seluruh warga masyarakat di wilayah Utan Kayu Selatan.

\section{Daftar Pustaka}

Hersya Pratama, R., Hakim, A., \& Shobaruddin Jurusan Administrasi Publik, M. (2128). PELAYANAN PUBLIK BERBASIS TEKNOLOGI INFORMASI DAN KOMUNIKASI (TIK), ELEKTRONIK RUKUN TETANGGA/RUKUN WARGA (e-RT/RW) (Studi e-Government di Kelurahan Ketintang Kecamatan Gayungan Pemerintah Kota Surabaya). In JAP) (Vol. 3, Issue 12).

Pauziah, U., Mustari, D., \& Akhirina, T. (2020). Social Service (PKM) of Application of Population Data Collection in RT. 004, Kalisuren. Mattawang: Jurnal Pengabdian Masyarakat, 1(2), 95-98. https://doi.org/10.35877/454ri.mattawang236

Seng Hansun, Muh. Salehuddin, dan M. B. K. (2021). Pengembangan dan Evaluasi Aplikasi e-RT di Kelurahan Periuk Kecamatan Periuk Kota Tangerang. 5.

Susano, A., \& Alva Mustika, F. (2017). PERANCANGAN APLIKASI PENGOLAHAN DATA ADMINISTRASI PENDUDUK PADA RUKUN TETANGGA WILAYAH KREO TANGERANG. In Jurnal String (Vol. 2, Issue 2).

Wahyudin, Fredy Rizqi Maulana, Mohammad Faisol, Yolanda, E. Z. (2021). Aplikasi Sistem Informasi Pelayanan Masyarakat Rukun Tetangga 02 Kelurahan Kalibaruberbasis Website. 2, 14-21.h 


\section{Daftar Hadir}

\begin{tabular}{|c|c|c|}
\hline \multicolumn{3}{|c|}{$\begin{array}{l}\text { Tanggal: } 30 / 11 / 2021 \\
\text { No Kegiata Arisan PKK RToou UKS }\end{array}$} \\
\hline 1. & Entin & 4 \\
\hline 2. & Ratit. & Dust \\
\hline 3. & Endat1. Yuliatun & \\
\hline 4. & Lasmini & \\
\hline g. & Saidat1. & \\
\hline 6. & Murdiati & H \\
\hline 7. & SUWARTI & Dowt \\
\hline 8. & SuHARti & Afer \\
\hline g & Narianti & 4 \\
\hline 10. & IbU YUNI & \\
\hline 11. & Sutiatl & 6 \\
\hline 12. & Sungiati & \\
\hline 13. & Bu EKi. & th \\
\hline 14. & worg inem & $\omega$ \\
\hline
\end{tabular}




\section{Surat Keterangan}

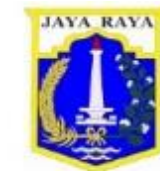

PEMERINTAH PROVINSI DAERAH KHUSUS IBU KOTA JAKARTA

PENGURUS RT. 004 RW.02

Kel. UTAN KAYU SELATAN, Kec. MATRAMAN

KOTAMADYA JAKARTA TIMUR

\section{SURAT KETERANGAN}

No. $130 / 004 / 02 / \mathrm{XI} / 2021$

Yang bertanda tangan dibawah ini
NAMA
JEBUL
ALAMAT
Jl. Nanas Raya No. 69 RT.004 RW.002
Kel. Utan Kayu Selatan, Kec. Matraman, Jakarta Timur 13120

Selaku Ketua RT.004/ RW.002 Kel. Utan Kayu Selatan, Kec. Matraman menyatakan bahwa:

1. KEVIN DIBERT A. PRATAMA TELUSSA (11207141)

2. TRININGTIAS SILALAHI (11207125)

3. INDAH FAJARWATI (11207054)

Telah melakukan kegiatan Pengabdian Kepada Masyarakat di wilayah kami pada tanggal 2 September - 31 November 2021. Kegiatan telah dilaksanakan dengan baik serta diterima warga dengan sangat antusias dan terjalin kerjasama dengan baik antara rekan mahasiswa dengan warga kami.

Demikian surat keterangan ini dibuat agar dapat dipergunakan sebagaimana mestinya.

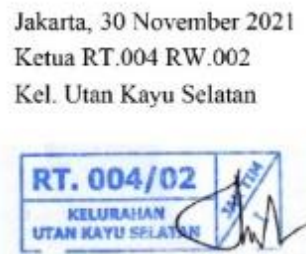

J E B U L 


\section{Foto Kegiatan}

Dokumentasi Kegiatan Pengabdian Kepada Masyarakat 2021
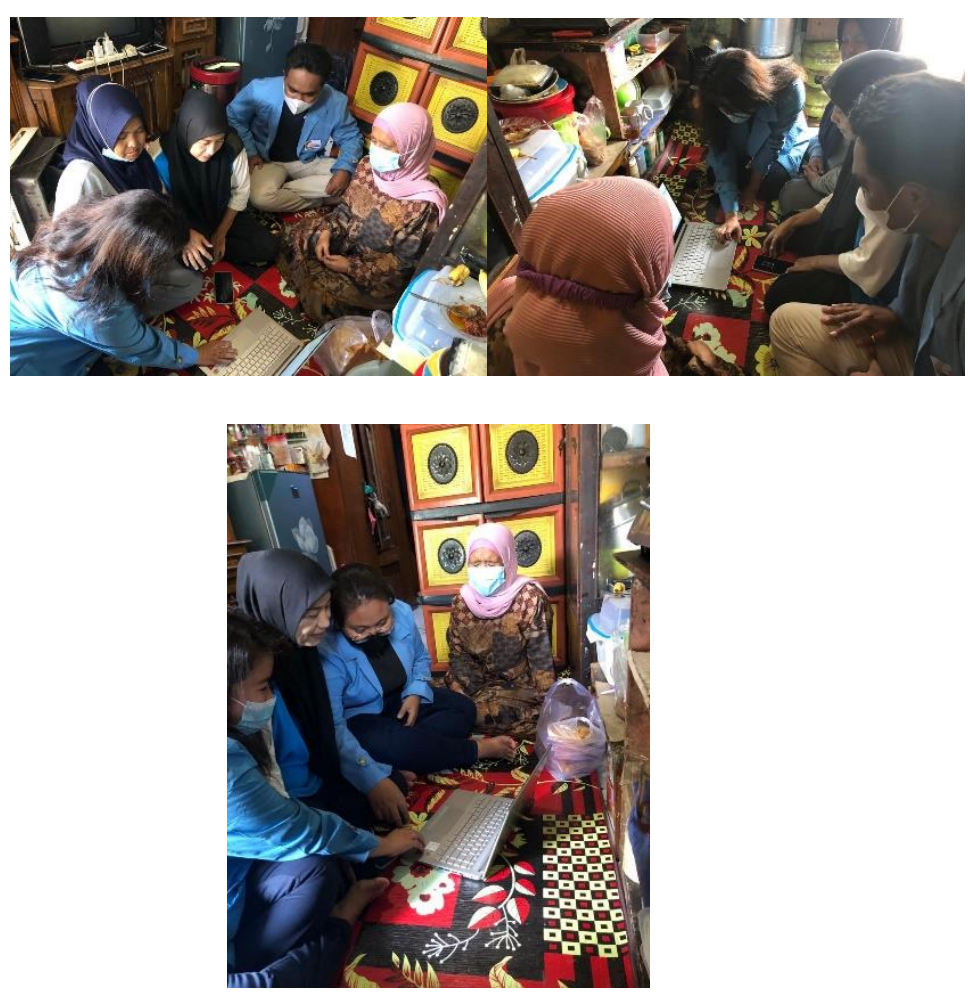